\title{
PENGARUH PEMBELAJARAN KOOPERATIF TIPE JIGSAW TERHADAP HASIL BELAJAR MATEMATIKA MATERI RELASI DAN FUNGSI
}

\author{
Vinsensius Supi ${ }^{1}$, Stefanus Notan Tupen ${ }^{2}$, Stefania Baptis Seto ${ }^{3}$ \\ ${ }^{1}$ Program Studi Pendidikan Matematika, Universitas Flores, Jln. Sam Ratulangi, Ende-Flores-NTT \\ ${ }^{2}$ Universitas Flores, Jln. Sam Ratulangi, Ende-Flores-NTT \\ ${ }^{3}$ Universitas Flores, Jln. Sam Ratulangi, Ende-Flores-NTT \\ Email : supivinsensius@gmail.com
}

\begin{abstract}
The purpose of this study was to determine student learning outcomes using the type of jigsaw cooperative learning model for relation and function material in class VIII students of SMPK Swadaya Maukaro in the 2019/2020 academic year. The type of research used is experimental research with a quantitative approach that begins with the preparation of a Learning Implementation Plan (RPP), Student Worksheets (LKS), and Learning Outcomes Test (THB). In this study, the population was all class VIII A students of SMPK Swadaya Maukaro Ende Tahin Ajaran 2019/2020. The sample taken was 20 students of class VIII with the technique used was simple random sampling (simple random technique). Data collected through tests of student learning outcomes. The data analysis technique used is covariance analysis (ANAKOVA) to determine the validity of the author's learning tools using the product-moment correlation formula. The results of the preparation of the type of jigsaw cooperative learning device produce good/valid learning tools. In this case, supported by analysis of covariance (ANAKOVA) with the results obtained by statistical F-count - 15.26179 and F - table- 4.15, it gives a significant value so it can be said that the type of jigsaw cooperative learning can improve student learning outcomes for relation and function material.
\end{abstract}

Keywords: jigsaw cooperative; relation and function.

\begin{abstract}
Abstrak
Tujuan penelitian ini adalah untuk megetahui hasil belajar siswa dengan menggunakan model pembelajaran kooperatif tipe jigsaw untuk materi relasi dan fungsi pada siswa kelas VIII SMPK Swadaya Maukaro tahun pelajaran 2019/2020. Jenis penelitian yang digunakan adalah penelitian eksperimen dengan pendekatan kuantitatif yang diawali dengan penyusunan Rencana Pelaksanaan Pembelajran (RPP), Lembar kerja Siswa (LKS), dan Tes Hasil Belajar (THB). Dalam penelitian ini yang menjadi populasi adalah seluruh siswa kelas VIII A SMPK Swadaya Maukaro Ende Tahun Ajaran 2019/2020. Sampel yang diambil adalah siswa kelas VIII sebanyak 20 orang dengan teknik yang digunakan adalah simple random sampling (teknik acak sederhana). Data yang dikumpulkan melalui tes hasil belajar siswa. Teknik analisis data yang digunakan adalah analisis kovarian (ANAKOVA) untuk mengetahui validitas perangkat pembelajaran penulis menggunakan rumus korelasi product moment. Hasil penyusunan perangkat pembelajaran kooperatif tipe jigsaw menghasilkan perangkat pembelajaran yang baik/valid. Dalam hal ini didukung oleh analisisi kovarian (ANAKOVA) dengan hasil diperoleh statistic F-hitung-15.26179 dan F - tabel- 4,15 maka memberi nilai yang signifikan sehingga dapat dikatakan bahwa pembelajaran kooperatif tipe jigsaw dapat meningkatkan hasil belajar siswa untuk materi relasi dan fungsi.
\end{abstract}

Kata kunci: kooperatif tipe jigsaw; relasi dan fungsi.

\section{PENDAHULUAN}

Matematika sebagai mata pelajaran yang berkaitan dengan konsep-konsep yang abstrak, maka dalam penyajian materi harus dapat disampaikan lebih menarik, agar dalam proses pembelajaran siswa lebih aktif dan termotivasi untuk belajar (Andriyanti, 2020). Terlihat pada pembelajaran di 
Pengaruh Pembelajaran Kooperatif Tipe Jigsaw Terhadap Hasil Belajar Matematika Materi Relasi dan Fungsi Vinsensius Supi ${ }^{1}$, Stefanus Notan Tupen ${ }^{2}$, Stefania Baptis Seto ${ }^{3}$

Jupika: Jurnal Pendidikan Matematika, Volume 3. Nomor 2. September 2020. Hal.131-140

kelas, banyak siswa masih menganggap matematika sebagai mata pelajaran yang sulit dan membosankan. Dengan anggapan tersebut menyebabkan kurangnya minat dan motivasi siswa untuk belajar matematika, sehingga hasilnya kurang optimal. Hal ini tentunya banyak faktor guru sebagai fasilitator dan pembelajaran yang digunakan oleh guru masih cenderung bersfat konvensional, sehingga pembelajaran matematika kurang disenangi, yang berakibat rendahnya hasil belajar siswa dalam mata pelajaran matematika.

Kenyataaan umum yang sering di jumpai sekolah menunjukan bahwa sebagaian besar proses pembelajaran matematika diberikan secara klasikal dengan model pembelajaran yang berfokus pada pemberian konsep yang bersifat hafalan dan proses pembelajaran masih didominasi oleh guru. Menurut Putra (2012) Pembelajaran yang didominasi oleh guru mengakibatkan siswa kurang mencerna materi secara efektif dan komunikatif dimana siswa hanya mendengar penjelasan guru dan kurang aktif dalam proses pembelajaran, sehingga berpengaruh rendahnya hasil belajar siswa.

Menurut Rudi (2010) "hasil belajar matematika berarti suatu kemampuan memahami konsep membedakan sejumlah konsep-konsep yang saling terpisah, serta kemampuan melakukan perhitungan secara bermakna pada situasi atau permasalahan-permasalahan yang lebih luas". Menurut Surya (1998), bahwa hasil belajar matematika adalah tingkat penguasaan yang di capai siswa dalam mengikuti proses belajar mengajar matematika sesuai dengan tujuan yang di tetapkan. Dengan demikian kemampuan hasil belajar matematika merupakan suatu kekuatan yang harus diperhatikan dan dilakukan secara fungsional dalam proses dan tujuan pembelajaran matematika.

Berdasarkan permasalahan diatas diperlukan adanya solusi yang digunakan untuk memperbaiki hasil belajar siswa. Cara yang dapat digunakan untuk memperbaiki hasil belajar yaitu guru harus mampu memilih dan menerapkan model pembelajaran yang dapat memotivasi siswa untuk lebih aktif dalam mengikuti pembelajaran agar kemampuan serta hasil belajar dapat lebih baik.

Model pembelajaran tipe jigsaw, dapat mendorong siswa lebih aktif serta memiliki rasa tanggung jawab lebih besar dalam pembelajaran. Lei (Rusman, 2014) menyatakan bahwa jigsaw merupakan salah satu tipe dari model pembelajaran yang fleksibel. Sejalan dengan pendapat di atas Hamdayama (2015) menyatakan model jigsaw cocok untuk semua kelas/tingkatan.

Proses pembelajaran dengan model pembelajaran kooperatif tipe jigsaw menurut tim MKPBM Suherman (2001) mengemukakan bahwa dalam jigsaw setiap anggota kelompok diberi tugas mempelajari topik tertentu yang berbeda, para siswa bertemu dengan anggota-anggota dari kelompok lain setelah itu mereka kembali ke kelompoknya semula untuk menyampaikan apa yang didapatkanya kepada teman-teman dikelompoknya, para siswa kemudian diberikan kuis/tes secara individual oleh guru. Skor hasil kuis atau tes tersebut disamping untuk menentukan skor individu juga digunakan untuk menentukan skor kelompoknya.

Hasil observasi yang dilakukan di SMPK Swadaya Maukaro di peroleh informasi bahwa matematika merupakan mata pelajaran yang dianggap sulit oleh siswa. Hasil wawancara peneliti 
Pengaruh Pembelajaran Kooperatif Tipe Jigsaw Terhadap Hasil Belajar Matematika Materi Relasi dan Fungsi Vinsensius Supi ${ }^{1}$, Stefanus Notan Tupen ${ }^{2}$, Stefania Baptis Seto ${ }^{3}$

Jupika: Jurnal Pendidikan Matematika, Volume 3. Nomor 2. September 2020. Hal.131-140

dengan guru kelas VIII, SMPK swadaya Maukaro didapat informasi bahwa pada pembelajaran dikelas guru menggunakan metode ceramah, tanya jawab dan penugasan, namun metode yang paling dominan digunakan yaitu metode ceramah. Pembelajaran dengan metode ceramah, guru merupakan subjek utama kegiatan pembelajaran (teacher centered). Selama kegiatan siswa tidak mengikuti pembelajaran dengan aktif sehingga pemahaman terhadap materi yang disampaikan juga tidak maksimal, hal ini berakibat tidak tercapainya tujuan pembelajaran.

Dalam penelitian ini akan diterapkan model pembelajaran kooperatif tipe jigsaw. Menurut Eggen \& Kauchak (Whardani, 2005), pembelajaran adalah pedoman berupa program atau petunjuk strategi mengajar yang di rancang untuk mencapai suatu pembelajaran. Salah satu model pembelajaran yang diterapkan adalah model pembelajaran kooperatif. Kata kooperatif berasal dari kata "cooperative" yang berarti kerja sama dalam mencapai tujuan.

Pembelajaran kooperatif tipe jigsaw dirancang untuk meningkatkan rasa tanggung jawab siswa terhadap pembelajaranya sendiri dan pembelajaran orang lain. Siswa tidak hanya mempelajari materi yang diberikan tetapi mereka juga harus siap untuk memberikan dan mengajarkan materi tersebut untuk anggota kelompok lainya. Dalam pembelajaran menggunakan model pembelajaran kooperatif tipe jigsaw siswa diberi kebebasan dan kesempatan untuk mengumpulkan informasi apa saja yang berkaitan dengan materi pembelajaran dan berbagai sumber belajar. Hal ini didukung oleh Penelitian yang dilakukan oleh Prasasti (2017) dengan judul pengaruh model pembelajaran kooperatif tipe jigsaw berbantuan alat peraga terhadap hasil belajar siswa kelas VIII pada materi fungsi MTS Sunan Kalijogo Kalidawir hasil penelitian yang dilakukan menunjukkan pengaruh yang signifikan pada pembelajaran kooperatif tipe Jigsaw terhadap hasil belajar matematika materi fungsi pada siswa.

\section{METODE}

Jenis penelitian yang digunakan dalam penelitian ini adalah penelitian eksperimen, dan pendekatan penelitian yang digunakan adalah pendekatan kuantitatif. Rancangan uji coba yang digunakan adalah one group pre-test post test design. Menurut Margono (2004), Populasi adalah keseluruhan data yang menjadi pusat perhatian seorang peneliti dalam ruang lingkup dan waktu yang telah ditentukan. Populasi berkaitan dengan data-data, jika seorang manusia memberikan suatu data, maka ukuran atau banyaknya populasi akan sama banyaknya manusia. Dalam penelitian ini yang menjadi populasi adalah siswa kelas VIII SMPK Swadaya Maukaro tahun pelajaran 2019/2020. Menurut Arikunto (2006), sampel adalah sebagian atau sebagai wakil populasi yang akan diteliti. Jika penelitian yang di lakukan sebagian dari populasi maka bisa dikatakan bahwa penelitian tersebut adalah penelitian sampel. Menurut Sugiyono (2008), sampel adalah bagian dari jumlah yang dimiliki oleh populasi. Dalam penelitian ini sampel yang diambil adalah siswa kelas VIII SMPK Swadaya Maukaro tahun pelajaran 2019/2020 sebanyak 20 orang. Teknik pengumpulan data yang dilakukan 
dalam penelitian ini adalah: 1) Teknik tes, 2) Teknik dokumentasi. Teknik analisis data yang digunakan adalah analisis kovarian (ANAKOVA).

\section{HASIL DAN PEMBAHASAN}

Pada tahap validasi pertama, validator menemukan kekeliruan dalam merancang perangkat pembelajaran yaitu, (1) langkah-langkah pembelajaran, dalam RPP yang peneliti susun belum sesuai dengan sintaks pembelajaran kooperatif tipe jigsaw, (2) jumlah masalah atau soal yang terdapat pada LKS tidak ideal dengan waktu yang tersedia, (3) soal yang dirancang pada THB terlalu banyak dan tidak sesuai dengan indikator yang ingin dicapai, serta soal untuk setiap nomor tidak diseratakan dengan kunci jawaban dan bobot. Karena itu berdasarkan masukan serta arahan dari validator maka peneliti merancang ulang RPP,LKS,dan THB.

Setelah peneliti merevisi perangkat pembelajaran langkah kedua peneliti melakukan validasi ulang pada validator dan hasil validasi ini validator mengatakan bahwa RPP, LKS, dan THB yang telah dirancang sudah sesuai dengan diharapkan, dan validator merekomendasikan untuk dilakukan ujicoba perangkat pada kelas uji coba.

Setelah selesai melaksanakan uji coba perangkat, peneliti menganalisis hasil pre-test dan posttest untuk mengetahui validitas, reliabilitas, dan sensitifitas butir. Hasil perhitungan validitas setiap butir tes dengan menggunakan rumus korelasi product moment disajikan pada tabel berikut:

Tabel 1. Validitas Butir Soal

\begin{tabular}{|c|l|l|l|}
\hline Nomor soal & \multicolumn{1}{|c|}{$\mathbf{1}$} & \multicolumn{1}{c|}{$\mathbf{2}$} & \multicolumn{1}{c|}{$\mathbf{3}$} \\
\hline $\boldsymbol{r}_{\boldsymbol{x y}}$ & 0,546783 & 0,857523 & 0,886742 \\
\hline Validitas & Cukup & Sangat tinggi & Sangat tinggi \\
\hline
\end{tabular}

Keterangan:

No Soal

:Nomor soal sesuai dengan tes hasil belajar (THB)

$r_{x y}$

:Nilai uji validitas perbutir soal sesuai dengan TesHasil Belajar(THB)

Validitas

:Kriteria validitas perbutir soal sesuai rentang nilai $r x_{y}$.

Berdasarkan kriteria kelayakan butir tes, maka setiap butir tes dikategorikan valid dan layak digunakan dalam penelitian.

Hasil perhitungan reliabilitas tes diperoleh koefisien reliabilitas sebesar 0,461505 dengan kriteria cukup. Kriteria ini memenuhi kriteria reliabel dan dapat digunakan untuk penelitian selanjutnya. Hasil perhitungan sensitivitas setiap butir diisajikan dalam tabel berikut.

Tabel 2. Perhitungan Sensitivitas Setiap Butir

\begin{tabular}{|l|c|c|c|}
\hline \multicolumn{1}{|c|}{ Nomor soal } & $\mathbf{1}$ & $\mathbf{2}$ & $\mathbf{3}$ \\
\hline Sensitivitas & 0,78 & 0,657143 & 0,8375 \\
\hline Interpretasi & Peka & Peka & Peka \\
\hline
\end{tabular}


Berdasarkan tabel di atas, dapat disimpulkan bahwa semua butir tes memenuhi kriteria sensitivitas sehingga layak digunakan dalam penelitian eksperimen.

Setelah selesai melaksanakan penelitian, selanjutnya peneliti memeriksa hasil pre-test dan posttes pada siswa kelas VIII SMPK Swadaya Maukaro yang kemudian dianalisis dengan statistik Anakova. Tujuannya adalah untuk mengetahui seberapa besar efek dari perlakuan, dalam hal ini adalah pemberian pembelajaran kooperati tipe jigsaw yang diberikan kepada siswa. Hasil analisisnya dapat dilihat pada tabel beikut.

Tabel 3. Persiapan Analisis Data

\begin{tabular}{|c|c|c|c|c|c|}
\hline Pre (X) & Post & $\begin{array}{c}\text { Perubahan } \\
(\mathbf{Y})\end{array}$ & Pre (X) & Post & $\begin{array}{c}\text { Perubahan } \\
(\mathbf{Y})\end{array}$ \\
\hline 55 & 100 & 45 & 20 & 80 & 60 \\
\hline 30 & 90 & 60 & 35 & 100 & 65 \\
\hline 35 & 90 & 55 & 40 & 90 & 50 \\
\hline 20 & 70 & 50 & 20 & 80 & 60 \\
\hline 35 & 80 & 45 & 35 & 100 & 65 \\
\hline 45 & 90 & 45 & 20 & 90 & 70 \\
\hline 45 & 90 & 45 & 15 & 85 & 70 \\
\hline 25 & 75 & 50 & 25 & 90 & 65 \\
\hline 50 & 100 & 50 & 20 & 80 & 60 \\
\hline 45 & 85 & 40 & 30 & 100 & 70 \\
\hline 385 & & $\mathbf{4 8 5}$ & $\mathbf{2 6 0}$ & & $\mathbf{6 3 5}$ \\
\hline $\mathbf{3 8 . 5}$ & & $\mathbf{4 8 . 5}$ & $\mathbf{2 6}$ & & $\mathbf{6 3 . 5}$ \\
\hline
\end{tabular}

Tabel 4. Hasil Reduksi Variabel $x$ dan Variabel y

\begin{tabular}{|c|c|c|c|c|c|c|c|}
\hline \multicolumn{2}{|c|}{$\mathbf{X}$} & \multicolumn{2}{c|}{$\mathbf{Y}$} & Tot X & Tot $\mathbf{T}$ & Tot(XY) & $\mathbf{X i}^{*} \mathbf{Y}$ \\
\hline 55 & 20 & 45 & 60 & 75 & 105 & 7875 & 3675 \\
\hline 30 & 35 & 60 & 65 & 65 & 125 & 8125 & 4075 \\
\hline 35 & 40 & 55 & 50 & 75 & 105 & 7875 & 3929 \\
\hline 20 & 20 & 50 & 60 & 40 & 110 & 4400 & 2200 \\
\hline 35 & 35 & 45 & 65 & 70 & 110 & 7700 & 3850 \\
\hline 45 & 20 & 45 & 70 & 65 & 115 & 7475 & 3425 \\
\hline 45 & 15 & 45 & 70 & 60 & 115 & 6900 & 3075 \\
\hline 25 & 25 & 50 & 65 & 50 & 115 & 5750 & 2875 \\
\hline 50 & 20 & 50 & 60 & 70 & 110 & 7700 & 3700 \\
\hline 45 & 30 & 40 & 70 & 75 & 110 & 8250 & 3900 \\
\hline $\mathbf{3 8 5}$ & $\mathbf{2 6 0}$ & $\mathbf{4 8 5}$ & $\mathbf{6 3 5}$ & $\mathbf{6 4 5}$ & $\mathbf{1 1 2 0}$ & $\mathbf{7 2 2 4 0 0}$ & $\mathbf{3 5 1 8 2 5}$ \\
\hline
\end{tabular}


Pengaruh Pembelajaran Kooperatif Tipe Jigsaw Terhadap Hasil Belajar Matematika Materi Relasi dan Fungsi Vinsensius Supi ${ }^{1}$, Stefanus Notan Tupen ${ }^{2}$, Stefania Baptis Seto ${ }^{3}$

Jupika: Jurnal Pendidikan Matematika, Volume 3. Nomor 2. September 2020. Hal.131-140

\begin{tabular}{|c|c|c|c|c|c|c|c|}
\hline \multicolumn{2}{|c|}{$X$} & \multicolumn{2}{c|}{$Y$} & Tot $X$ & Tot $Y$ & Tot $(X Y)$ & Xi*Yi \\
\hline 38.5 & 26 & 48.5 & 63.5 & 416025 & 1254400 & & \\
\hline 148225 & 67600 & 235225 & 403225 & 20801.25 & 62720 & 36120 & 35182.5 \\
\hline 14822.5 & 6760 & 23522.5 & 40322.5 & 32.25 & 56 & & \\
\hline & 215825 & & 638450 & & & & \\
\hline & 21582.5 & & 63845 & & & & \\
\hline
\end{tabular}

Karena adanya korelasi antara variabel $\mathrm{X}$ dan variabel $\mathrm{Y}$, maka langkah pertama adalah memurnikan variabel $\mathrm{Y}$ dari variabel konkomitan (pengiring) $\mathrm{X}$, atau memperoleh $\mathrm{Y}$ yang disesuaikan atau dikoreksi.

Tabel 5. Koreksi Variabel $x$ dan Variabel $y$

\begin{tabular}{|c|c|c|c|c|c|c|c|c|}
\hline \multicolumn{2}{|c|}{$\mathbf{X}^{\wedge} \mathbf{2}$} & \multicolumn{2}{c|}{$\mathbf{Y}^{\wedge} \mathbf{2}$} & \multicolumn{2}{c|}{ XY } & $\begin{array}{c}\text { Tot } \\
\left(\mathbf{X}^{\wedge 2}\right)\end{array}$ & $\begin{array}{c}\text { Tot } \\
\left(\mathbf{Y}^{\wedge} \mathbf{2}\right)\end{array}$ & Tot (XY) \\
\hline 3025 & 400 & 2025 & 3600 & 2475 & 1200 & 3425 & 5625 & 3675 \\
\hline 900 & 1225 & 3600 & 4225 & 1800 & 2275 & 2125 & 7825 & 4075 \\
\hline 1225 & 1600 & 3025 & 2500 & 1925 & 2000 & 2825 & 5525 & 3925 \\
\hline 400 & 400 & 2500 & 3600 & 1000 & 1200 & 800 & 6100 & 2200 \\
\hline 1225 & 1225 & 2025 & 4225 & 1575 & 2275 & 2450 & 6250 & 3850 \\
\hline 2025 & 400 & 2025 & 4900 & 2025 & 1400 & 2425 & 6925 & 3425 \\
\hline 2025 & 225 & 2025 & 4900 & 2025 & 1050 & 2250 & 6925 & 3075 \\
\hline 625 & 625 & 2500 & 4225 & 1250 & 1625 & 1250 & 6725 & 2875 \\
\hline 2500 & 400 & 2500 & 3600 & 2500 & 1200 & 2900 & 6100 & 3700 \\
\hline 2025 & 900 & 1600 & 4900 & 1800 & 2100 & 2925 & 6500 & 3900 \\
\hline $\mathbf{1 5 9 7 5}$ & $\mathbf{7 4 0 0}$ & $\mathbf{2 3 8 2 5}$ & $\mathbf{4 0 6 7 5}$ & $\mathbf{1 8 3 7 5}$ & $\mathbf{1 6 3 2 5}$ & $\mathbf{2 3 3 7 5}$ & $\mathbf{6 4 5 0 0}$ & 34700 \\
\hline
\end{tabular}

Koreksi atau penyesuaian karena adanya regresi $\mathrm{Y}$ atas $\mathrm{X}$ terhadap jumlah kuadrat variabel $\mathrm{Y}$ dapat dihitung dengan:

Jumlah Total

$J_{E}^{1}=J K(Y$ dikoreksi $)=T_{Y Y}-\frac{\left(T_{X Y}\right)^{2}}{T_{X X}}=996.5517$

Dalam Perlakuan Kelompok:

$J_{E}^{1}=J K(Y$ dikoreksi $)=E_{Y Y}-\frac{\left(E_{X Y}\right)^{2}}{E_{X X}}=525.122$

Antar Kelompok

$J_{E}^{1}=J K(Y$ dikoreksi $)=471.430$

Dari hasil perhitungan ini selanjutnya disajikan dalam tabel ANAKOVA berikut. 
Pengaruh Pembelajaran Kooperatif Tipe Jigsaw Terhadap Hasil Belajar Matematika Materi Relasi dan Fungsi

Vinsensius Supi ${ }^{1}$, Stefanus Notan Tupen ${ }^{2}$, Stefania Baptis Seto ${ }^{3}$

Jupika: Jurnal Pendidikan Matematika, Volume 3. Nomor 2. September 2020. Hal.131-140

Tabel 6. Daftar Anakova Model Pembelajaran

\begin{tabular}{|l|c|c|c|c|c|c|c|c|}
\hline \multirow{2}{*}{ Sumber Variasi } & \multirow{2}{*}{ dk } & \multicolumn{2}{|c|}{ JK dan Produk silang } & \multicolumn{3}{c|}{ Dikoreksi } & \\
\cline { 3 - 9 } & & Y & XY & X & Y & Dk & KT & F \\
\hline Antar Kelompok & 1 & 1125 & -937.5 & 781.25 & & & & \\
\hline Dalam Kelompok & 18 & 655 & -482.5 & 1792.5 & 525.122 & 17 & 30.88953 & \\
\hline Jumlah & 19 & 1780 & -1420 & 2573.75 & 996.5517 & 18 & & \\
\hline Antar Kelompok & & & & & 471.4297 & 1 & 471.4297 & 15.26179 \\
\hline
\end{tabular}

Dari tabel ANAKOVA di atas, untuk menguji efek pembelajaran dalam kelompok eksperimen terhadap respon Y setelah dimurnikan dari variabel konkomitan $\mathrm{X}$, diperoleh statistik $\mathrm{F}=15.26179$ dengan dk pembilang 1 dan dk penyebut 17 , memberikan nilai yang signifikan ( $F$ tabel $=4,15$ ).

Regresi Dalam Perlakuan

Dengan memperhatikan model ANAKOVA yaitu:

$$
\begin{aligned}
Y_{i j}=\mu+\beta\left(X_{i j}-\bar{X}\right)+\tau_{i}+\varepsilon_{i j} \quad i & =1,2, \ldots, k \\
j & =1,2, \ldots, n_{k},
\end{aligned}
$$

Nilai parameter yang diduga dengan metode kuadrat terkecil:

Koefisien regresi $\beta$ ditaksir oleh: $b=\frac{E_{X Y}}{E_{X X}}$

$$
b=-0.27
$$

$\mu$ ditaksir oleh: $\frac{J_{Y . .}}{N}$

$$
\mu=\frac{\Sigma y}{n}=56.00
$$

$\tau_{i}$ ditaksir oleh: $\frac{J_{Y i .}}{n_{i}}-b\left(\frac{J_{X i .}}{n_{i}}-\frac{J_{X . .}}{N}\right)$

Perlakuan A $\left(\tau_{A}\right)=50.18236$

Perlakuan B $\left(\tau_{B}\right)=61.81764$

Tabel 7. Nilai Rata-rata Kelompok

\begin{tabular}{|c|c|c|}
\hline $\begin{array}{c}\text { Perlakuan } \\
\text { Kelompok }\end{array}$ & $\begin{array}{c}\text { Rata-rata } \\
\text { dikoreksi }\end{array}$ & $\begin{array}{c}\text { Rata-rata tidak } \\
\text { dikoreksi }\end{array}$ \\
\hline A & 50.18 & 48.5 \\
\hline B & 61.82 & 63.5 \\
\hline
\end{tabular}

Dari tabel tersebut di atas tampak bahwa perbedaan rata-rata yang dikoreksi atau disesuaikan harga-harganya lebih kecil perbedaannya dari yang satu dengan yang lainnya jika dibandingkan dengan rata-rata yang tidak dikoreksi. 


\section{Pemeriksaan Residual}

Setelah diperoleh nilai estimasi parameter, maka langkah selanjutnya adalah melakukan uji normalitas residual. Pengujian kenormalan residual menggunakan uji Kolmogorov-Smirnov dengan hipotesis sebagai berikut:

$H_{0}$ : Residual berdistribusi normal

$H_{l}$ : Residual tidak berdistribusi normal

Regression Analysis: Mutlak Residual versus

Uji identik dengan hipotesis sebagai berikut :

$$
H_{0}: \sigma_{1}^{2}=\sigma_{2}^{2}=\ldots=\sigma_{n}^{2}=\sigma^{2}
$$

$H_{l}$ : minimal ada satu $\sigma_{i}^{2} \neq \sigma^{2}, \quad i=1,2, \ldots, n$

Pada tingkat signifikansi 5\%.Nilai F-hitung $=0.34<$ F-tabel $=4.15$ atau dapat dilihat nilai Pvalue $0.567>\alpha=0,05$ yang menyimpulkan bahwa dalam kasus ini varians telah homogen.

Uji independen dapat dilakukan dengan hipotesis sebagai berikut:

$H_{0}: \rho_{i}=0$ atau residual tidak berkorelasi

$H_{1}: \rho_{i} \neq 0 \quad$ residual berkorelasi

$\alpha=0,05$

Durbin-Watson statistic $=2.22062$

Pada tingkat signifikansi 5\%.Nilai P-value $=0.567>\alpha=0,05$ yang menyimpulkan bahwa dalam kasus ini residual tidak berkorelasi atau gagal tolak $\mathrm{H}_{0}$. Dengan kriteria Durbin Watson tes $d=2.22062 \square 2$ tidak ada korelasi antar residual.

Pengujian normalitas dapat dilakukan dengan hipotesis sebagai berikut.

$H_{0}:$ Residual berdistribusi normal

$H_{l}$ : Residual tidak berdistribusi normal

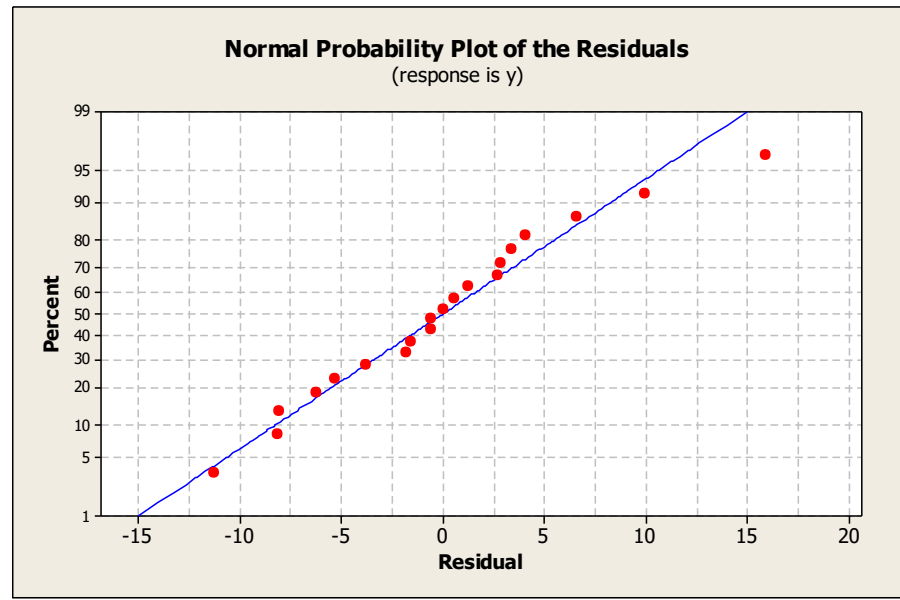

Gambar 1. Plot Normalitas Residual 
Plot normalitas residual menunjukkan tidak ada penyimpangan terhadap distribusi normal. Hal ini diperkuat dengan menggunakan uji Kolmogorov-Smirnov yang memberikan P-value $=0,567>0,05$ sehingga gagal tolak $\mathrm{H}_{0}$ atau residual berdistribusi normal.

\section{KESIMPULAN}

Berdasarkan uraian pada bab sebelumnya dan hasil analisis data yang diperoleh, maka dapat disimpulkan bahwa 1) Pengembangan perangkat pembelajaran kooperatif tipe jigsaw untuk materi relasi dan fungsi yang baik/valid. Adapun perangkat pembelajaran yang dihasilkan adalah rencana pelaksanaan pembelajaran (RPP), lembar kerja siswa (LKS), dan tes hasil belajar (THB). 2) Hasil analisis deskriptif menunjukkan bahwa perangkat pembelajaran kooperatif tipe jigsaw layak digunakan untuk materi relasi dan fungsi karena ketuntatasan belajar mencapai 100\%. Pendekatan kooperatif tipe jigsaw meningkatkan hasil belajar siswa karena, dari table ANAKOVA di atas, untuk menguji efek pembelajaran dalam kelompok eksperimen terhadap respon $\mathrm{Y}$ setelah di murnikan dari variabel konkomitan $\mathrm{X}$, diperoleh statistic $\mathrm{F}=15.26179$ dengan $\mathrm{dk}$ pembilang $=1 \mathrm{dan} \mathrm{dk}$ penyebut $=$ 17 memberikan nilai yang signifikan, ( $\mathrm{F}$ tabel $=4,15)$.

\section{DAFTAR PUSTAKA}

Andriyanti, M. (2020). Penerapan Media Pembelajaran Monopoli Matematika (MONIKA) untuk Materi Aritmatika Sosial Pada Siswa Kelas VII SMP Swasta Adhyaksa Tahun Ajaran 2018/2019. Scientifical Colloquia: Jurnal Pendidikan Matematika Universitas Flores Volume 3., Nomor 1, Hal. 16-22. Maret 2020.

Arikunto, S. 2006. Metode Penelitian Kualitatif. Jakarta: Bumi Aksara.

Hamdayama, J. (2015). Model dan Metode Pembelajaran Kreatif dan Berkarakter. Bogor: Ghalia Indonesia.

Margono. (2004). Metodologi Penelitian Pendidikan. Jakarta: PT Rineka Cipta.

Prasasti, N. F. E. (2017). Pengaruh Model Pembelajaran Kooperatif Tipe Jigsaw Berbantuan Alat Peraga terhadap Hasil Belajar Siswa Kelas VIII Pada Materi Fungsi MTs Sunan Kalijogo Kalidawir. SKRIPSI. http://repo.iain-tulungagung.ac.id/5353/.

Putra, A. S. (2012). Penerapan Metode Pembelajaran Example Non Example Pada Mata Pelajaran Pekerjaan Mekanik Dasar Kelistrikan Kelas X di SMK Negeri 2 Yogyakarta. Skripsi. https://core.ac.uk/download/pdf/78028028.pdf.

Rudi. (2010). Penuntun Dasar-Dasar Pemisahan Analitik. Kendari:Universitas Haluoleo.

Sugiyono. (2008). Metode Penelitian Pendekatan Kuantitaf, dan R \& D. Bandung: CV. Alfabeta.

Suherman, E. (2001). Strategi Pembelajaran Matematika Kontemporer. Bandung: JICA-UPI.

Surya, M. (1998). Dasar-dasar Konseling Pendidikan (Teori dan Konsep). Yogyakarta: Kota Kembang. 
Pengaruh Pembelajaran Kooperatif Tipe Jigsaw Terhadap Hasil Belajar Matematika Materi Relasi dan Fungsi Vinsensius Supi ${ }^{1}$, Stefanus Notan Tupen ${ }^{2}$, Stefania Baptis Seto ${ }^{3}$

Jupika: Jurnal Pendidikan Matematika, Volume 3. Nomor 2. September 2020. Hal.131-140

Rusman. (2010). Model-Model Pembelajaran Mengembangkan Profesionalisme Guru. Jakarta: PT.

Raja Grafindo Persada.

Whardani. (2005). Dasar-dasar Komunikasi Dan Keterampilan Dasar Mengajar. Jakarta: UT. 